\title{
PRESENTATION OF RESOURCE-SAVING TECHNOLOGY FOR PRODUCING SCANDIUM COMPOUNDS FROM DIOPSIDE
}

\author{
${ }^{1}$ Alexandra ZAYTSEVA, 'Evgenii KUZIN, ${ }^{1}$ Natalya KRUCHININA, ${ }^{2}$ Sergey GALAKTIONOV, \\ ${ }^{2}$ Alexandr KRASNOSCHEKOV \\ ${ }^{1}$ Mendeleev University of Chemical Technology, Moscow, Russia, e.n.kuzin@mail.ru \\ ${ }^{2}$ «Rock Capital Partners» Limited Liability Company", Moscow, Russia, Sergey.Galaktionov@rockcp.ru
}

https://doi.org/10.37904/metal.2021.4253

\begin{abstract}
As part of the work, a low-waste resource-saving technology for processing diopside with the extraction of scandium compounds and the associated production of a wide range of large-tonnage mineral products has been developed. The technology of solid-phase extraction of scandium compounds using solid impregnates based on macroporous activated carbons modified with phosphonic acids has been proposed. The main directions of neutralization and processing of mother liquors and solid products formed in the process of extracting scandium compounds are proposed. Samples of magnesium fertilizers, red pigments for building mixtures, as well as precursors of titanium compounds were obtained as commercial products.
\end{abstract}

Keywords: Scandium, diopside, extraction, magnesium, titanium

\section{INTRODUCTION}

The development of industry leads to the need to search for and develop new materials with improved performance characteristics. Steel structures, despite their reliability and durability, cannot always be used in certain industries. Such exceptions include space, aviation and other industries. To the materials used in these directions, in addition to the strength factor, the condition of minimizing the weight is applied, since the use of heavy and dense materials significantly increases the cost and operating costs of the device produced.

To solve such problems, materials based on compounds of magnesium, titanium and aluminum have become widespread; however, in their pure form, these metals do not provide the required strength. To improve this characteristic, alloying additives are introduced into the composition of materials. From the data of various sources [1] it is known that the addition of scandium compounds significantly increases the strength of aluminum alloys and makes it possible to use the resulting alloy in the directions described above.

Scandium is a scattered element, the content of which in rocks rarely exceeds $0.01 \%$ of the mass. The scandium mining process is usually combined with the processes of large-scale mineral concentrates to obtain various products. To date, hydrolytic sulphuric acid, a product of processing titanium minerals by the sulphuric acid method [2], uranium mining solutions [3,4], as well as solid ash and slag waste [5] and red mud - waste of overgrowth of bauxite by the method Bayer $[6,7]$.

Liquid extraction processes are used to extract scandium from acid solutions of processing various mineral components. A traditional extractant for solving such problems is a mixture of Di (2-ethylhexyl) phosphoric acid and tributyl phosphate in kerosene [8-10]. The use of a flammable liquid, as well as significant losses of the extractant in the form of an emulsion, significantly increase the cost of the process, which is why the task of developing an effective technology for extracting scandium remains urgent. An equally urgent task is the search for new sources of raw materials for the production of scandium compounds, while the products formed in the process of processing will be in demand on the market. 
The authors of the work within the framework of preliminary studies [11,12] put forward an assumption about the possibility of using diopside, a mineral from the pyroxene group, as a raw material for the production of scandium, which at the same time is a valuable source of magnesium compounds.

The main purpose of this work is to present the results of work on the development of an integrated energy and resource-saving, environmentally friendly and safe production technology for processing diopside with the extraction of scandium and for the production of a wide range of mineral products.

\section{MATERIALS AND METHODS}

The starting point was a sulphuric acid solution of the process of opening diopside [11,12], which is already successfully used at the present time. Sodium-silicon fluoride in an amount of up to $20 \mathrm{~g} / \mathrm{I}$ was used as an additive to increase the efficiency of opening. The solution was filtered through a polymer vacuum filter to separate unreacted ore and insoluble silicon and calcium-containing sediments.

The study of the chemical composition of acidic solutions was carried out using a Spectroskai atomic emission spectrometer with magnetic plasma (Korolev, Russia) [13]. The study of the chemical composition of solid samples was carried out on a scanning electron microscope with a 1610LV with an energy dispersive spectrometer for electron probe microanalysis SSD X-Max Inca Energy (JEOL, Japan; Oxford Instruments, Great Britain).

Samples of impregnates for the extraction of scandium compounds were obtained by impregnating macroporous coals (MAC, $А Г 3, B C K$ grades) with a mixture of tributyl phosphate (hereinafter TBP) and di (2ethylhexyl) phosphoric acid (hereinafter D2EHPA).

\section{RESULTS AND DISCUSSION}

The chemical composition of sulphuric acid solutions is presented in Table 1.

Table 1 Chemical composition of sulphuric acid solutions of diopside leaching

\begin{tabular}{|c|c|c|c|c|c|c|}
\hline Elements & $\mathrm{Sc}(\mathrm{mg} / \mathrm{l})$ & $\mathrm{Ti}(\mathrm{g} / \mathrm{l})$ & $\mathrm{Ca}(\mathrm{g} / \mathrm{l})$ & $\mathrm{Fe}(\mathrm{g} / \mathrm{l})$ & $\mathrm{Mg}(\mathrm{g} / \mathrm{l})$ & $\mathrm{Al}(\mathrm{g} / \mathrm{l})$ \\
\hline Concentrations & 12.1 & 0.65 & 0.42 & 17.0 & 15.9 & 6.15 \\
\hline
\end{tabular}

From the data in Table 1, it can be seen that in the process of opening diopside, $20 \%$ sulphuric acid solutions with an extremely high content of various metals (titanium, aluminum, iron) are formed. Significant concentrations of magnesium compounds were found in the composition of solutions, which makes it possible to theoretically organize their extraction to obtain magnesium sulphate (fertilizer). In addition to metal salts, the solution contains a fluoride ion (up to $10 \mathrm{~g} / \mathrm{l}$ ), the return of which to the opening stage will significantly reduce the cost of the products obtained.

At the next stage of the experiments, the process of extraction of scandium compounds on samples of impregnates was investigated. Data on the dynamic exchange capacity of impregnates with respect to scandium are presented in the diagram in Figure 1.

From the data of the diagram in Figure 1 that the samples of impregnates have a relatively high capacity in relation to scandium compounds and allow them to be extracted with high efficiency and selectivity from the sulphuric acid solution of diopside processing. Compounds of titanium, iron, aluminum and other impurities almost completely remain in the mother liquor. The residual concentration of scandium compounds in the solution was at the level of $0.001 \mathrm{mg} / \mathrm{l}$ (the detection limit of the device). Re-extraction of scandium compounds was carried out with a mixture of ammonium hydrofluoride and sulphate, with the degree of scandium reextraction exceeding $80 \%$. To isolate solid scandium-containing concentrates, precipitation is carried out in the form of fluorides, oxalates or hydroxides. 


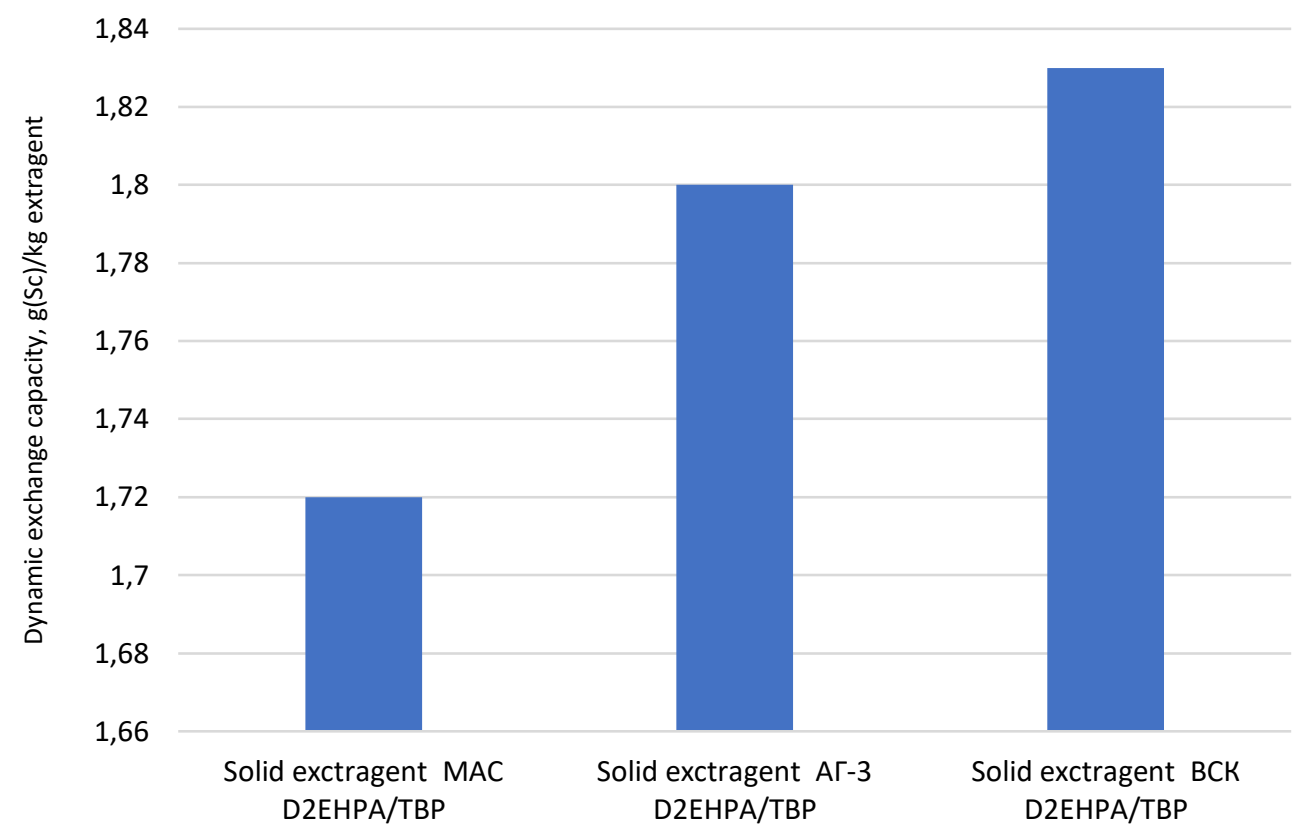

Figure 1 Dynamic exchange capacity

Magnesium oxide was introduced into the mother liquor containing free fraction in the form of a suspension. In the process of neutralization and increase in $\mathrm{pH}$, fluorides and hydroxides of titanium, iron, aluminum and other impurities were precipitated from the solution, and magnesium sulphate remained in the solution due to its good solubility. Data on the chemical composition of solutions obtained in the neutralization process are presented in Table 2.

Table 2 Chemical composition of solutions of the process of neutralization of free sulphuric acid

\begin{tabular}{|c|c|c|c|c|c|c|}
\hline & \multicolumn{5}{|c|}{ Concentration (g/l) } & \multirow{2}{*}{$\begin{array}{c}\mathrm{pH} \text { after } \\
\text { neutralization }\end{array}$} \\
\cline { 2 - 6 } & $\mathrm{Ti}$ & $\mathrm{Ca}$ & $\mathrm{Fe}$ & $\mathrm{Mg}$ & $\mathrm{Al}$ & \\
\hline Alkaline reagent $\mathrm{MgO}$ & $<0.001$ & 0.16 & $<0.001$ & 42.3 & $<0.001$ & 8.54 \\
\hline
\end{tabular}

From the data in Table 2, it can be seen that the use of magnesium oxide (147 g/l) allows with high efficiency to remove impurities of heavy metals from the mother liquor. Most of the fluorides have also passed into the sediment and can be returned to the ore opening stage.

The solution that has passed the drying stage is a mixture (in terms of oxides):

94.6 wt\% MgO, $2.1 \mathrm{wt} \% \mathrm{Na}_{2} \mathrm{O}, 1.7 \mathrm{wt} \% \mathrm{SiO}_{2}, 0.8 \mathrm{wt} \% \mathrm{CaO}, 0.9 \mathrm{wt} \% \mathrm{TiO}_{2}, \mathrm{Fe}_{2} \mathrm{O}_{3}, \mathrm{Al}_{2} \mathrm{O}_{3}$

Comparing the data on the chemical composition of the solid product and the requirements of regulatory documents, we can conclude that the obtained magnesium sulphate can be used as a fertilizer [14].

The precipitate of hydroxides and fluorides of aluminum, iron, titanium and other elements obtained in the process of neutralization was calcined at a temperature of $950{ }^{\circ} \mathrm{C}$ for 60 minutes. The composition of the resulting product: iron $25.3 \mathrm{wt} \%$, aluminum $10 \mathrm{wt} \%$, magnesium $11 \mathrm{wt} \%$, titanium $1.3 \mathrm{wt} \%$, calcium $0.6 \mathrm{wt} \%$, oxygen $51.8 \mathrm{wt} \%$. This product can be used as an inexpensive pigment for the production of building products, as well as an iron ore raw material for the production of metallic iron.

An enlarged scheme of diopside processing, considering the technological solutions described in the work, is shown in Figure 2. 


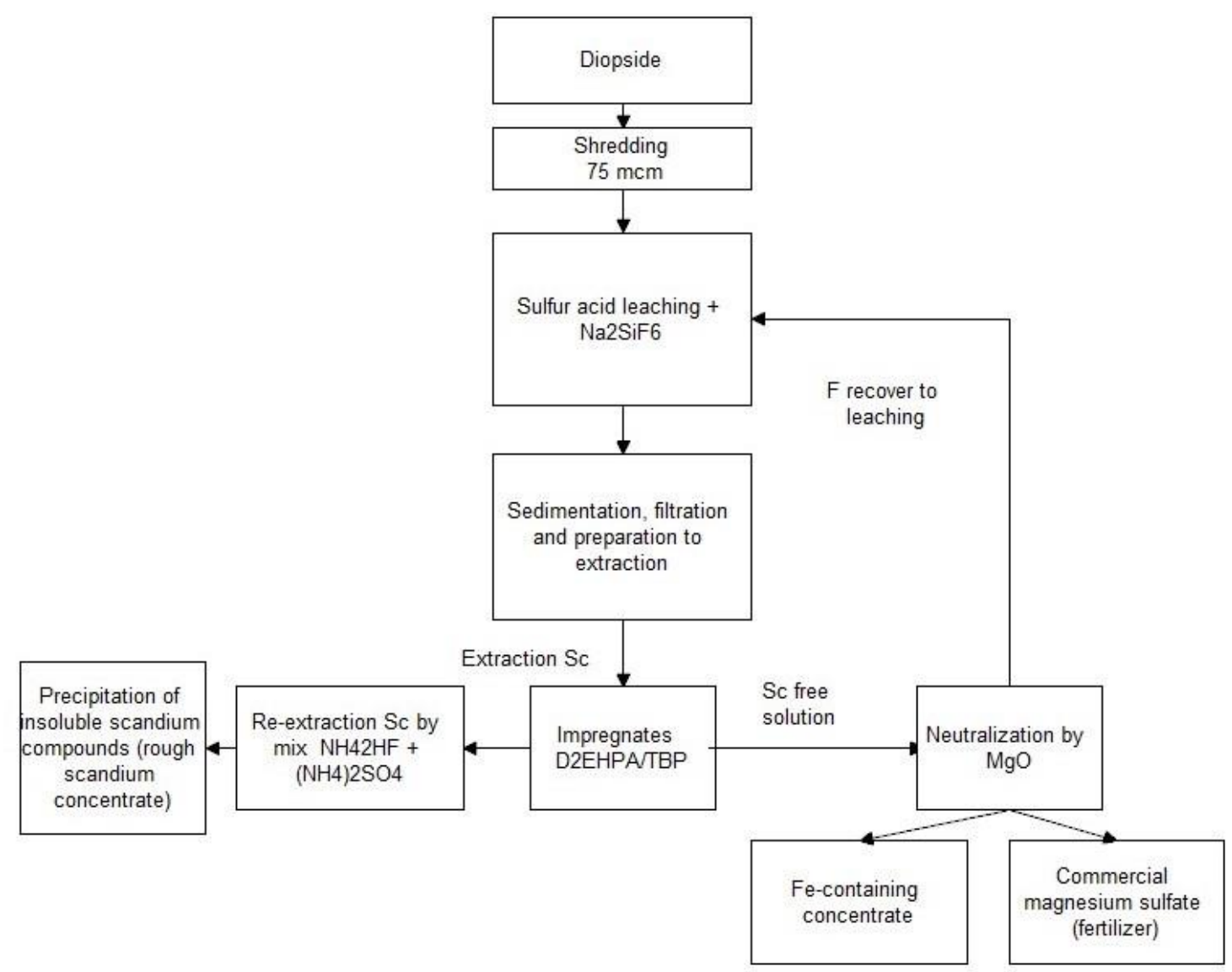

Figure 2 Schematic diagram of energy-and resource-saving technology for processing diopside

\section{CONCLUSION}

The presented data demonstrate innovative approaches to organizing the diopside processing process to obtain scandium compounds and large-tonnage mineral products (fertilizers, pigments). A technology for the extraction (extraction) of scandium compounds using impregnates based on macroporous coals impregnated with a mixture of tributyl phosphate (hereinafter TBP) and di(2-ethylhexyl) phosphoric acid (hereinafter D2EHPA) has been proposed. A high exchange capacity of impregnates with respect to scandium compounds is noted. The possibility of re-extraction of scandium compounds using a binary mixture of ammonium hydrofluoride and sulphate is proposed. In this case, the efficiency of this mixture in the process of scandium re-extraction exceeds $80 \%$.

A technology has been proposed for the neutralization of sulphate mother liquors by neutralization with magnesium oxide, while magnesium sulphate, a fertilizer for the needs of agriculture, is obtained as products with the extraction of compounds of iron, aluminum and titanium, which can be used as iron ore raw materials or pigments for building materials.

A conceptual diagram of an energy- and resource-saving, environmentally safe production technology for processing diopside with obtaining scandium concentrates and a wide range of large-tonnage mineral products is proposed.

\section{ACKNOWLEDGEMENTS}

This work was supported by «Rock Capital Partners» Limited Liability Company 


\section{REFERENCES}

[1] LI, G., YE, Q., DENG, B., LUO, J., RAO, M., PENG, Z., JIANG, T. Extraction of scandium from scandium-rich material derived from bauxite ore residues. Hydrometallurgy. 2018, vol. 176. pp. 62-68.

[2] AKIMOVA, I.D., CHUMAKOVA, G.M., MOLCHANOVA, T.V., GOLOVKO, V.V. Obtaining scandium concentrate by liquid extraction from hydrolytic sulphuric acid effluents from titanium dioxide production. Non-ferrous metals 2017, vol. 3. pp. 63-68

[3] SMIRNOV, A.L., TITOVA, S.M., RYCHKOV, V.N., BUNKOV, G.M., SEMENISHCHEV, V.S., KIRILLOV, E.V., SVIRSKY, I.A. Study of scandium and thorium sorption from uranium leach liquors. Journal of Radioanalytical and Nuclear Chemistry. 2017, vol. 312, no. 2, pp. 277-283.

[4] RYCHKOV, V.N., SEMENISHCHEV, V.S., MASHKOVTSEV, M.A., KIRILLOV, E.V., KIRILLOV, S.V., BUNKOV, G.M., BOTALOV, M.S. Deactivation of the scandium concentrate recovered from uranium leach liquors. Journal of Radioanalytical and Nuclear Chemistry. 2016, vol. 310, no. 3, pp. 1247-1253.

[5] KSENOFONTOV B.S., KOZODAEV, A.S., TARANOV, R.A., VINOGRADOV, M.S., VOROPAEVA, A.A., SENIK, E.V. Development of a complex technology for leaching rare earth metals from ash and slag and the problem of concentration of solutions of these metals. Modern science-intensive technologies. 2016, vol. 3/1, pp. 44-49;

[6] PETERS, E. M., KAYA, Ş., DITTRICH, C., FORSBERG, K. Recovery of scandium by crystallization techniques. Journal of Sustainable Metallurgy. 2019, vol. 5, no. 1, pp. 48-56.

[7] ZHANG, N., LI, H.-X., LIU, X.-M. Recovery of scandium from bauxite residue-red mud: a review. Rare Metals. 2016, vol. 35, no. 12. pp. 887-900.

[8] WANG, W., PRANOLO, Y., CHENG, C.Y. Metallurgical processes for scandium recovery from various resources: A review. Hydrometallurgy. 2011, vol. 108, no. 1-2, pp. 100-108.

[9] BOLSHAKOV, K.A. Chemistry and technology of rare and trace elements, Part 2. Ed. Textbooks for universities. Moscow: Higher school, 1976.

[10] StePANOV, S.I., P'El, K. H., BOYARINTSEV, A.V., GIGANOV, V. G. , CHEKMAREV, A.M., AUNG, M.M. Use of machining to increase the recovery of scandium from efractory silicate raw material. Theoretical Foundations of Chemical Engineering. 2018, vol. 52, no. 5. pp. 973-977.

[11] KUZIN, E.N., KRUCHININA, N.E., GALAKTIONOV, S.S., KRASNOSHCHEKOV, A.N. Neutralization of sulphuric acid solutions in the complex processing of diopside enrichment products. Obogashenie Rud. 2019, vol. 4. pp. 3843.

[12] KUZIN, E.N., KRUCHININA, N.Ye., ZAITSEVA, A.D., GALAKTIONOV, S.S., KRASNOSHCHEKOV, A.N. Assessment of the possibilities of using solid extractants based on D2EHPA / TBP in the processes of scandium extraction from sulphuric acid processing solutions diopside. Bulletin of Kazan Technical University. 2020, vol. 23, no. 1, pp. 64-68.

[13] KUCHUMOV, V.A., SHUMKIN, S.S. Analysis of the chemical composition of the initial alloy in the production of permanent magnets from alloys of the Sm-Co system. Scientific-technical department of St. Petersburg State Polytechnic University. 2017, vol. 23, no. 1, pp. 219-225.

[14] GRADE A TU 2141-025-32496445-01 Technical magnesium sulphate (magnesium sulphate) 